\title{
Using a simple 2D steady-state saturated flow and reactive transport model to elucidate denitrification patterns in a hillslope aquifer
}

\author{
$\underline{\text { S.J.R. Woodward }}^{\text {a }}$, R. Stenger ${ }^{\text {a }}$ and V. Bidwell ${ }^{\text {b }}$ \\ ${ }^{a}$ Lincoln Ventures Limited, Private Bag 3062, Hamilton, New Zealand \\ ${ }^{b}$ Lincoln Ventures Limited, PO Box 133, Lincoln, New Zealand \\ Email: simon.woodward@lvl.co.nz
}

\begin{abstract}
In the last 50 years, agricultural intensification has resulted in increasing nutrient losses that threaten the health of the lakes on the volcanic plateau of New Zealand's North Island. As part of our efforts to understand the transport and transformations of nitrogen in this landscape, the 2D vertical groundwater transport model AquiferSim 2DV was used to simulate water flow, nitrate transport, denitrification, and discharge to surface waters in a hillslope adjacent to a wetland and stream discharging into Lake Taupo, Australasia's largest lake.
\end{abstract}

AquiferSim 2DV is a steady state model using the finite-difference stream function method for flow modelling and finite-volume mixing cell method for contaminant transport modelling. The ratio of horizontal to vertical hydraulic conductivity must be specified within the aquifer domain, as must effective porosity and denitrification rates. Boundary conditions consist of recharge fluxes and contaminant concentrations, as well as the assumed zone of discharge. Hydrodynamic dispersion is simulated through numerical dispersion, which depends on grid resolution. Denitrification reactions within each computational cell may include both zero-order and first-order rates. All parameters may be spatially heterogeneous.

Previous applications of this model have been to essentially horizontal aquifer systems. By contrast, this hillslope system has sloping material layers and a dynamic and sloping water table. Extensions were made to AquiferSim 2DV, including representation of converging/diverging flow, which allowed a 2D steady-state model of this system to be developed.

Comparison of model predictions with detailed water level and hydrochemical data from the site, however, showed that the model's attractive simplicity in this case precluded adequate characterisation of what is essentially a $3 \mathrm{D}$, transient system. While the model produced reasonable agreement with the concentration patterns under an average water table profile, predictions of oxygen and nitrate concentrations under low summer and high spring water table conditions were poor. The seasonal changes reflected an annual recharge pulse of fresh, oxidised water followed by gradual oxygen depletion till the next recharge pulse occurs in the following year, an essentially transient phenomenon which could not be represented using a steady state model. This in itself has provoked fresh thinking about the dynamic nature of flow and chemistry at the site.

Keywords: Ground water model, stream function, mixing cell, first order kinetics, hill pasture 


\section{INTRODUCTION}

Quantifying denitrification occurring in an aquifer is hindered by difficulty in obtaining detailed information about the subsurface environment. The characteristics and spatial extent of material units, hydraulic conductivities and zones of potential denitrification can often only be defined hypothetically. Yet the ability to estimate removal of nitrate is essential to quantifying the groundwater system's assimilative capacity for nitrate and understanding the impacts of land use on contamination of subsurface water and environmentally sensitive receiving surface waters.

We wished to develop a simple tool that could be used to quickly estimate aquifer denitrification based on minimal data. Initial work focused on estimating contamination and denitrification patterns in horizontal aquifers, using the steady-state finite difference/finite volume model AquiferSim 2DV (Woodward et al., 2010). The motivation for this was understanding and managing nitrate leaching from agricultural land, particularly new dairy conversions, into the important Canterbury Plains aquifers of New Zealand's South Island (Bidwell, 2005; Bidwell et al., 2005).

However, the main focus of our North Island field research is on nitrate contamination from hill farming (Stenger et al., 2008, 2010), which comprises around 35\% of New Zealand's agricultural land. This paper describes adaptation of the AquiferSim 2DV model to study nitrate leaching from hill pastures. In particular, we wished to understand the main flow and denitrification processes producing the dissolved oxygen (DO) and nitrate nitrogen (NN) patterns observed at our Waihora well field.

\section{FIELD SITE}

The Waihora well field is located in the headwaters of the Tutaeuaua Stream, which drains into Lake Taupo in the central North Island of New Zealand, as described in Stenger et al. (2010). Figure 1 shows material and water table data from wells on the main downslope transect, which is approximately $100 \mathrm{~m}$ long with an average ground surface slope of around $10 \%$.

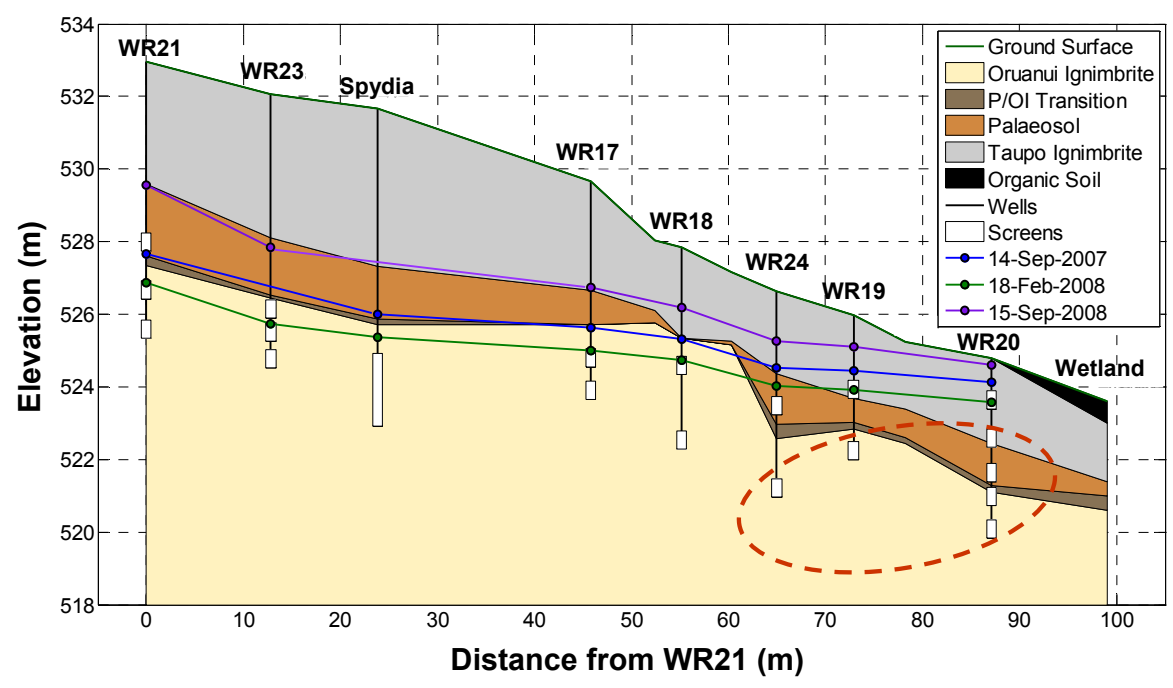

Figure 1: $\quad$ Taupo site cross section, showing well screen locations, material layers and water table profiles on three dates. $\mathrm{P} / \mathrm{OI}$ is Palaeosol/Oruanui ignimbrite transitional material. The dotted region indicates wells that usually draw reduced water.

The water table profiles in Figure 1 represent average (14 September 2007), low (18 February 2008) and high (15 September 2008) water table scenarios. On each of these dates, DO and NN concentrations were analysed in each well screen, among other data. These show a tendency for deeper water to be reduced (low DO and $\mathrm{NN}$ ), particularly in the lower portion of the site, upslope of the wetland. It has been hypothesised that relict woody debris from the vegetation destroyed by the Taupo eruption (1.8 ka BP) provides a carbon source for heterotrophic denitrification in this part of the site (Stenger et al., 2009), but the relationship between this debris and water flowpaths leading to the reduced water in the lower observation wells is not yet clear.

\section{HILLSLOPE MODEL}

AquiferSim 2DV is a steady state groundwater flow and contaminant transport model which was developed to predict contaminant flow paths and attenuation in a 2D vertical cross section of an aquifer (Bidwell et al., 
2005). It uses the node-centred stream function method for flow (Fogg and Senger, 1985) and the blockcentred mixing cell method for contaminant transport (Rao and Hathaway, 1989). The ratio of horizontal and vertical hydraulic conductivity must be specified within each model cell, as must effective porosity and denitrification rates (zero and/or first order). Boundary conditions consist of recharge fluxes and contaminant concentrations, as well as assumed discharge fluxes. Well abstractions (if any) must be assumed to occur on the model boundary only. Dispersion is simulated using numerical dispersion, which depends on grid resolution, as a proxy. All parameters may be spatially heterogeneous.

AquiferSim 2DV has been verified by comparison with two analytical solutions, and with a MODFLOW/MT3D example (Woodward and Burbery, unpublished report).

In order to adapt AquiferSim 2DV to model hillslope flow and transport, the following changes were made:

- Sloping material zones, linked to hydraulic conductivity and chemical reaction rates;

- Sloping water table, and adjustable "bedrock" position;

- Non-constant aquifer "width" to simulate converging or diverging flow;

- Implementation of observation wells;

- Complex specified flux boundary conditions at the upstream boundary (i.e. non-zero flux);

- Simple coupled oxygen-nitrate reaction model;

- Calculation of water velocity.

The model was coded as a Microsoft Excel 2003 spreadsheet, and solved using Excel's “iteration" feature. The $100 \mathrm{~m}$ by $20 \mathrm{~m}$ model domain was constructed using a regular finite difference grid, 200 cells long and 50 cells deep. Each cell was therefore $0.5 \mathrm{~m}$ long and $0.4 \mathrm{~m}$ deep, which simulated horizontal and vertical dispersivities of $0.25 \mathrm{~m}$ and $0.2 \mathrm{~m}$ respectively.

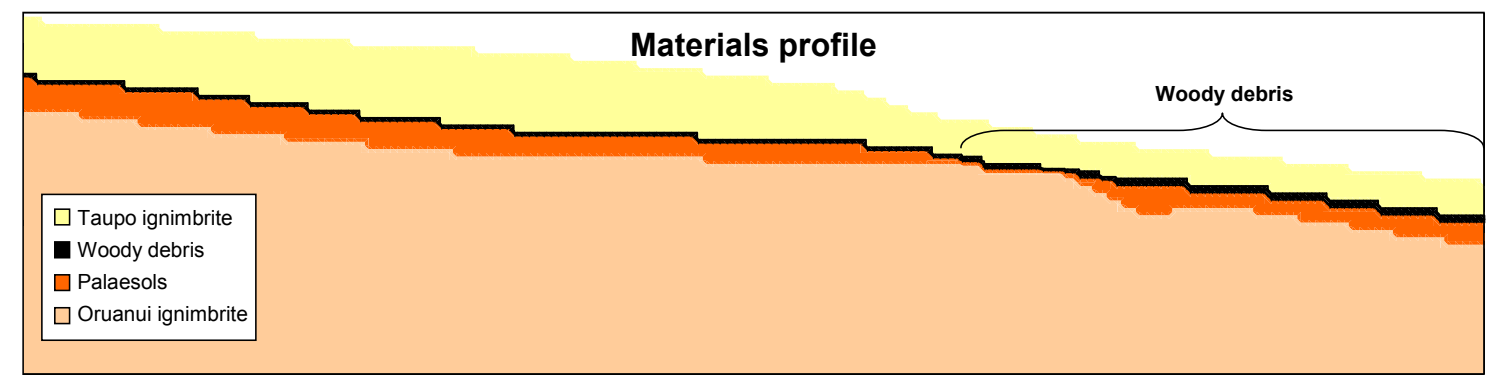

Figure 2: $\quad$ Aquifer material layers. The rectangular model domain is $100 \mathrm{~m}$ long and $20 \mathrm{~m}$ thick ( 200 cells by 50 cells). A layer of woody debris is included only in the indicated region.

The aquifer material layers were linearly interpolated to the bore records (Figure 2). A 0.4 m thick "Woody debris" layer was included immediately above the Palaeosol in the lower portion of the site only (where it is permanently below the water table) to represent organic material still remaining from the vegetation destroyed by the Taupo eruption $(1.8 \mathrm{ka} \mathrm{BP})$. This material is thought to provide carbon as an electron donor for heterotrophic denitrification at the site. $\mathrm{P} / \mathrm{OI}$ transitional material was not considered as distinct from the Oruanui ignimbrite.

Material hydraulic parameters used in this model are given in Table 1, and are based on the lab measurements reported in Wöhling et al. (2008). Saturated hydraulic conductivity $K_{\text {sat }}\left(\mathrm{m} \mathrm{y}^{-1}\right)$ was assumed to be isotropic, and decline exponentially with depth, such that $K_{\mathrm{sat}}(z)=K_{\max } \exp (-r z)$, with $z(\mathrm{~m})$ being depth within each material layer and $r$ the length scale $\left(\mathrm{m}^{-1}\right)$. Reaction parameters $f o_{1}\left(\mathrm{y}^{-1}\right)$ and $f o_{2}\left(\mathrm{y}^{-1}\right)$ are described below.

Table 1: $\quad$ Material hydraulic and reaction parameters.

\begin{tabular}{|l|c|c|c|c|c|}
\hline & $\boldsymbol{K}_{\max }\left(\mathbf{m ~ y}^{-1}\right)$ & $\boldsymbol{r}\left(\mathbf{m}^{-1}\right)$ & Porosity & $\boldsymbol{f o}_{1}\left(\mathbf{y}^{-1}\right)$ & $f_{\mathbf{o}_{2}}\left(\mathbf{y}^{-1}\right)$ \\
\hline Taupo ignimbrite & 896 & 0.32 & 0.641 & 0.3 & 20 \\
\hline Woody debris & 183 & 0 & 0.686 & 30 & 200 \\
\hline Palaeosols & 183 & 0.4 & 0.686 & 0.3 & 20 \\
\hline Oruanui Ignimbrite & 60 & 0.5 & 0.573 & 0.3 & 20 \\
\hline
\end{tabular}

\section{SATURATED FLOW}

Water table location was also linearly interpolated to well observations (Figure 3). This produced an irregular saturated zone for model calculations. In the first instance, water table data from 14 September 2007 were used, which was a "typical" spring water table. 
Groundwater flow is obtained by solving the stream function equation (Fogg and Senger, 1985):

$$
\frac{\partial}{\partial x}\left(\frac{1}{K_{\text {sat }}} \frac{\partial S}{\partial x}\right)+\frac{\partial}{\partial z}\left(\frac{1}{K_{\text {sat }}} \frac{\partial S}{\partial z}\right)=0
$$

where the horizontal $\left(q_{x}\right)$ and vertical $\left(q_{z}\right)$ components of groundwater flux are related to stream function $S$ as follows:

$$
q_{x}=-\frac{\partial S}{\partial z}, \quad q_{z}=\frac{\partial S}{\partial x}
$$

Flow boundary conditions in AquiferSim 2DV are specified flux. Constant fluxes of $0.6659 \mathrm{~m} / \mathrm{y}$ and 0 were applied as water table recharge and at the bottom of the model domain, respectively. Influx at the left hand boundary was estimated using a larger scale version of the same model, and totalled $120.25 \mathrm{~m}^{3} / \mathrm{m} / \mathrm{y}$. This meant that there was $186.84 \mathrm{~m}^{3} / \mathrm{m} / \mathrm{y}$ outflux at the right hand end $\left(0.6659 \mathrm{~m} / \mathrm{y} \times 100 \mathrm{~m}+120.25 \mathrm{~m}^{3} / \mathrm{m} / \mathrm{y}\right)$, which was distributed with depth in proportion with $K_{\text {sat }}$.

The boundary conditions give the values of $S$ for all boundary nodes ( $S$ is equal to the cumulative flux summed anticlockwise around the boundary), and Equation 2 is then solved for the internal nodes using a node-centred finite difference method. The contours of the solution $S$ are the streamlines of flow, and pairs of adjacent contours define "stream tubes". Each stream tube carries the same flux, so closer contours indicate faster flow (Figure 3 and 4).

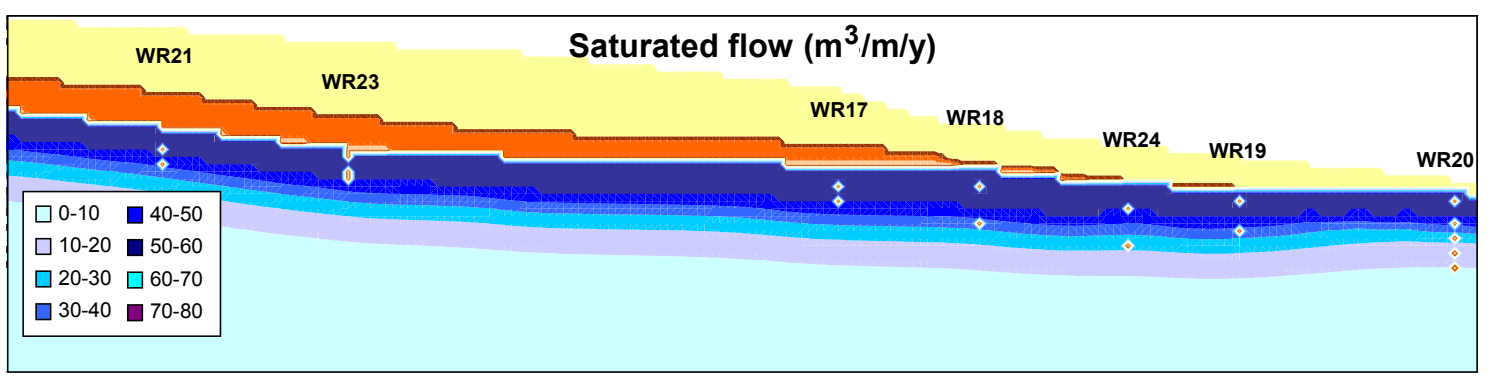

Figure 3: $\quad$ Stream function flow solution for a typical water table. Well screen locations are indicated by dots. The unsaturated zone is coloured as in Figure 2.

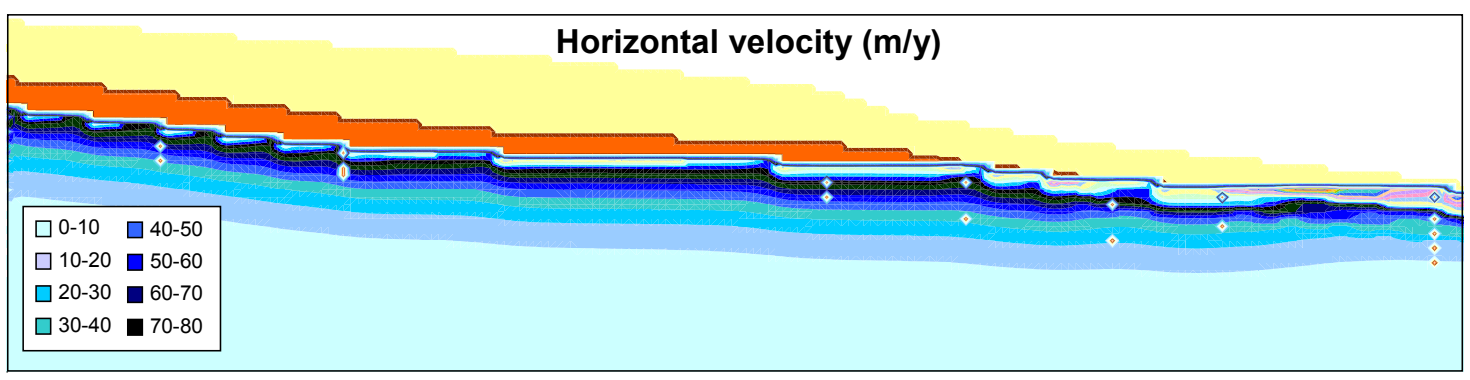

Figure 4: Horizontal velocity corresponding to Figure 3. The unsaturated zone is coloured as in Figure 2.

The flow solution in Figures 3 and 4 shows the downslope (left to right) flow lines and the horizontal component of velocity respectively. Flow runs approximately parallel to the water table, and rises towards the surface at the downstream boundary (where the water table emerges into a wetland and stream).

Horizontal velocity is greatest near the water table, and declines rapidly with depth. Velocity also increase from left to right, to a maximum of more than $250 \mathrm{~m} / \mathrm{y}$ near the downstream boundary. Actual field velocities observed in tracer experiments at the site may be even higher than this (Clague, unpublished data).

\section{SOLUTE TRANSPORT}

Having obtained the flow solution, AquiferSim 2DV then solves the solute transport problem using a blockcentred finite difference mixing cell approach (Rao and Hathaway, 1989), where the advective solute fluxes entering and leaving each grid cell face are calculated using the stream function solution at the nodes 
surrounding the cell and the concentrations in the adjacent cells. The method produces numerical dispersion, whose magnitude can be controlled by changing the dimensions of the cells. In this way, hydrodynamic dispersion may be simulated.

Transport boundary conditions are specified in the form of fixed concentration blocks surrounding the model domain. Oxygen and nitrate concentrations in ground water recharge were set at 10 and $3 \mathrm{~g} / \mathrm{m}^{3}$ respectively, upstream concentrations were estimated using a larger scale version of the same model, and concentrations were assumed to be zero at the bottom.

Dissolved oxygen was assumed to be depleted at a first order reaction rate of $f o_{1}$ (Table 1), and nitrate was assumed to be depleted at a first order reaction rate equal to:

$$
f o_{2}\left(\frac{1}{2}-\frac{1}{\pi} \arctan \left(10 \times\left(C_{O}-0.2\right)\right)\right)
$$

where $\mathrm{fO}_{2}$ is the maximum first order rate, and $C_{O}$ is the dissolved oxygen concentration in $\mathrm{g} / \mathrm{m}^{3}$ (Kinzelbach et al., 1991). The bracketed term decreases from near 1 towards 0 as dissolved oxygen increases. Reaction rates in the woody debris layer were assumed to be orders of magnitude higher than those in the other material layers (Table 1), reflecting the supply of carbon substrate, which we believe facilitates oxygen reduction and heterotrophic denitrification at this site. The other aquifer materials are typically low in organic matter.

Figure 6 shows the DO concentrations calculated for the typical water table scenario of Figure 3, and Figure 7 shows the corresponding NN concentrations. DO declines with depth, as observed in the observation wells. Depletion of oxygen due to aerobic decomposition of the woody debris in the shallow groundwater is evident in the downslope end of the transect.

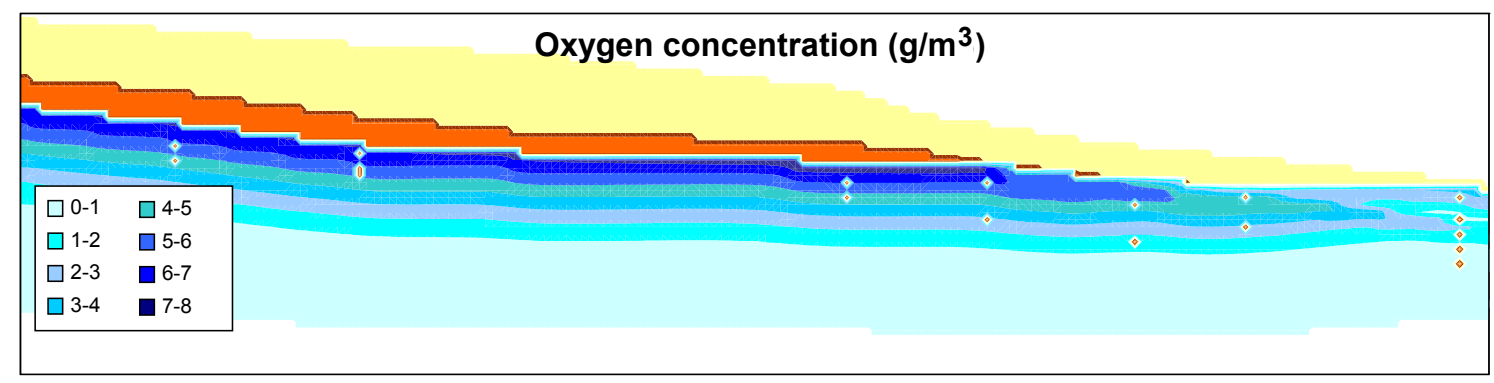

Figure 6: $\quad$ Oxygen concentration in the aquifer. The unsaturated zone is coloured as in Figure 2.

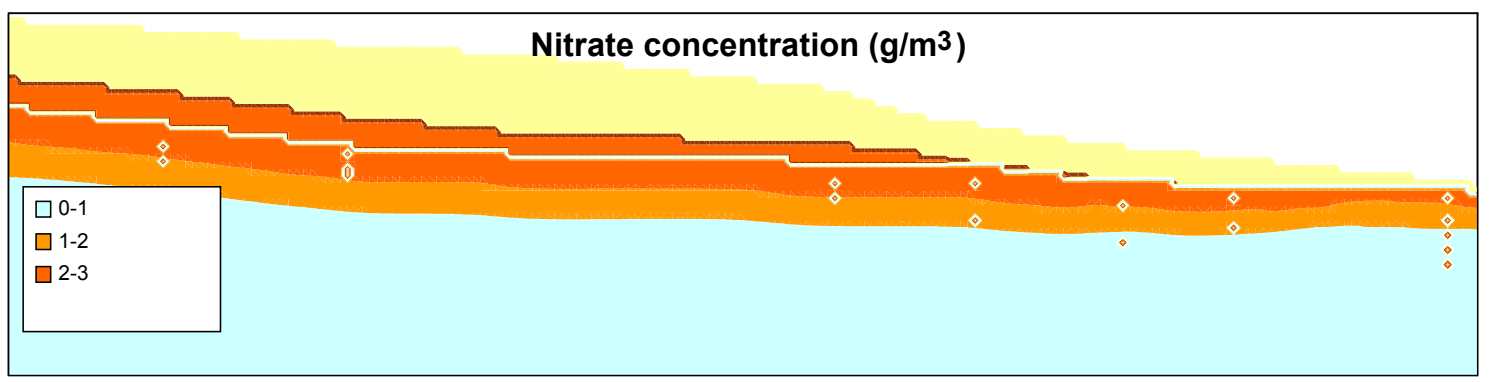

Figure 7: $\quad$ Nitrate concentration in the aquifer. The unsaturated zone is coloured as in Figure 2.

Nitrate concentrations remain relatively constant in the shallower, oxidised water, then drop rapidly once oxygen is depleted. Again, because of oxygen depletion as water passes through the woody debris, denitrification is enhanced in this region, leading to lower NN concentrations, as observed in the lower wells.

\section{INTERPRETATION}

The boundary concentrations of oxygen and nitrate, material reaction rates and reaction coupling were manually adjusted to achieve agreement with the field data (the solute concentrations in the observation wells) for the 14 September 2008 (typical water table) scenario (Figure 8b). A formal inverse modelling study was not undertaken; the aim was simply to ascertain whether this model had to potential to explain the observed patterns, not to estimate parameters in a rigorous fashion. 
Reasonable agreement was achieved to the typical water table scenario at many of the well screens, although results in the middle of the site (wells WR17 and WR18) were not fitted as well as the other wells. This may indicate differences in hydraulic or chemical properties near these wells, where in contrast to all other sites no Palaeosol was found.

The same parameters were then used to simulate concentrations for low and high water table scenarios (Figure 8a,c).

(a)
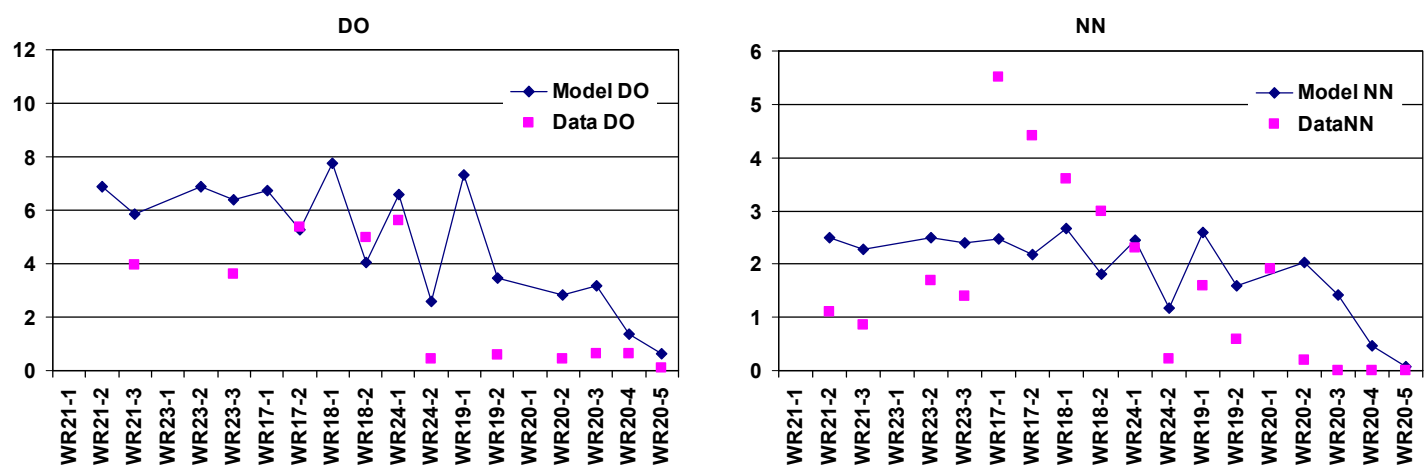

(b)
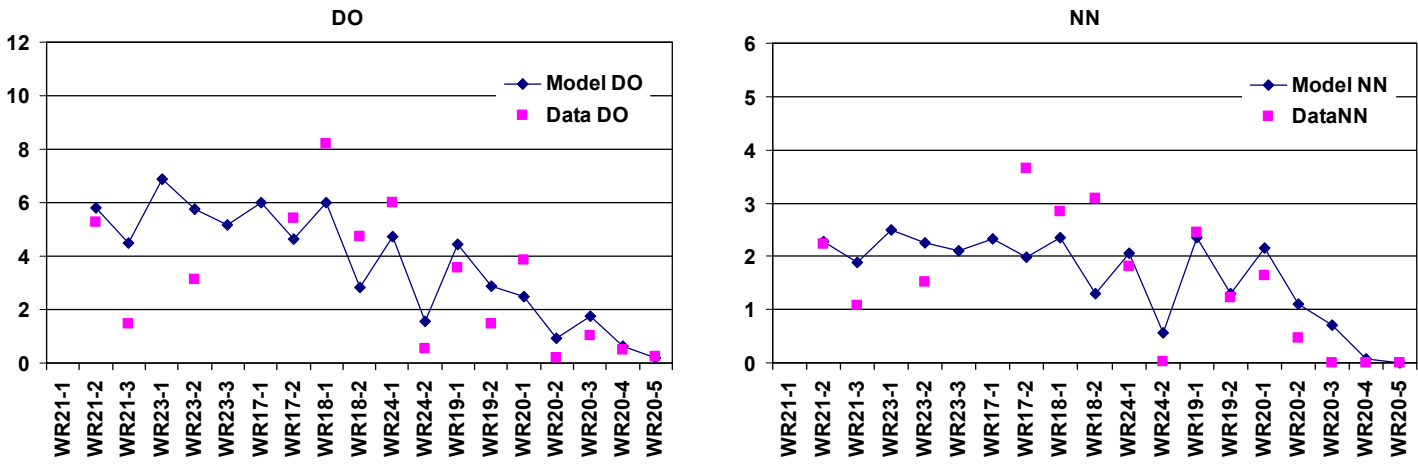

(c)
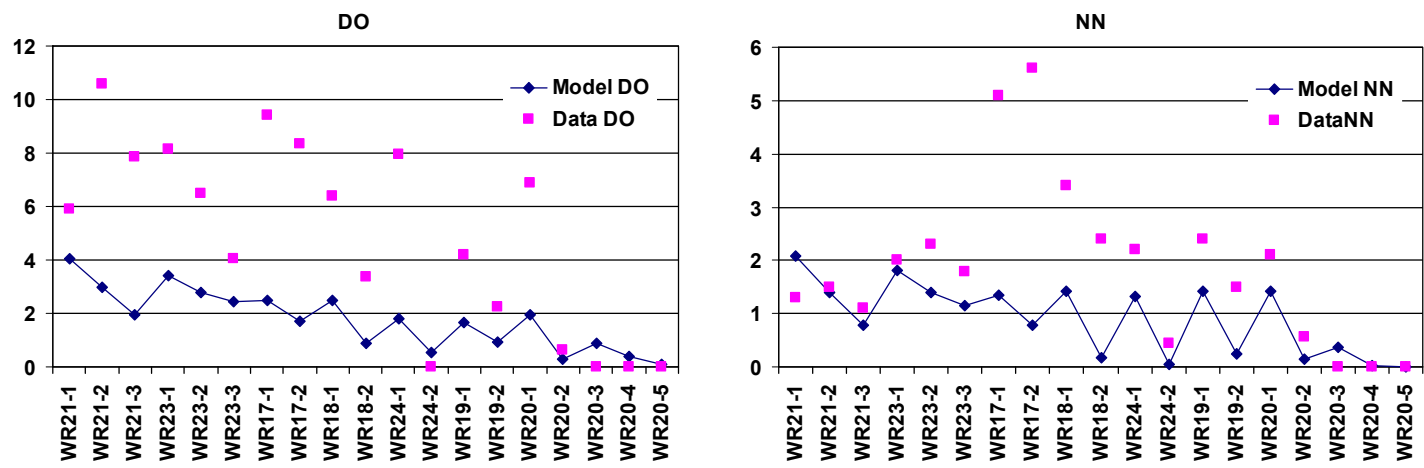

Figure 8: $\quad$ Comparison of model predictions with observed DO and NN concentrations $\left(\mathrm{g} / \mathrm{m}^{3}\right)$ at each well screen for the (a) low water table (18 February 2008), (b) typical water table (14 September 2007) and (c) high water table (15 September 2008) scenarios.

The data show DO concentrations at the same well screen increasing as the water table rises, while the nitrate concentrations were similar at all water table levels. However, the opposite patterns are produced by the model - as the well screens are deeper below the water table, predicted DO concentrations fall (and NN to a lesser extent), because greater reduction occurs above the well screen. In reality, the redox boundary remains 
Woodward et al., 2D steady state saturated flow and transport model

at a similar elevation, and the higher water level in winter consists of fresh recharge, which is high in oxygen (Stenger et al., 2010). The steady-state model was not able to reproduce this.

\section{CONCLUSIONS}

Despite its simplicity, it was possible to adapt AquiferSim 2DV to simulate flow and chemistry in a hillslope with a typical water table profile. However, changing the water table to high/low water table conditions did not produce the concentration patterns observed in the measurements. It may not be possible to reproduce these dynamics using a steady-state model. While a steady state model is attractive for its simplicity, it is only relevant to situations and scales where transient behaviour is relatively unimportant. Given the small scale of our field site (100 m long transect), complex stratigraphy and strong annual dynamics, a steady state model may not be able to represent the essential features of the system. We have therefore returned to using a full 3D transient model in our analysis of this site (Wang et al., 2003; Woodward et al., 2009).

\section{ACKNOWLEDGMENTS}

This work was funded under the New Zealand Foundation for Research, Science and Technology "Groundwater Quality" (LVLX0302) and "Groundwater Assimilative Capacity" (C03X1001) contracts.

\section{REFERENCES}

Bidwell, V.J. (2005). Groundwater recharge interface and nitrate discharge: Central Canterbury, New Zealand. In: Acworth, R.I., Macky, G., and Merrick, N.P. (eds.) Proceedings of the NZHS-IAH-NZSSS 2005 Conference, 28 November-2 December 2005, Auckland, Paper I17.

Bidwell, V.J., Lilburne, L.R., and Good, J.M. (2005). Strategy for developing GIS-based tools for management of the effects on groundwater of nitrate leaching from agricultural land use. In: MODSIM 2005: International Congress on Modelling and Simulation. Modelling and Simulation Society of Australia and New Zealand, December 2005.

Fogg, G.E., and Senger, R.K. (1985). Automatic generation of flow nets with conventional ground-water modeling algorithms. Ground Water, 23(3): 336-344.

Kinzelbach, W., Schäfer, W., and Herzer, J. (1991). Numerical modeling of natural and enhanced denitrification processes in aquifers. Water Resources Research, 27, 1123-1135.

Rao, B.K., and Hathaway, D.L. (1989). A three-dimensional mixing cell solute transport model and its application. Ground Water, 27(4): 509-516.

Stenger, R., Barkle, G.F., Burgess, C., Wall, A., and Clague, J. (2008). Low nitrate contamination of shallow groundwater in spite of intensive dairying: the effect of reducing conditions in the vadose zone-aquifer continuum. Journal of Hydrology (NZ), 47(1), 1-24.

Stenger, R., Clague, J., and Wall, A. (2009). Groundwater nitrate attenuation in a volcanic environment (Lake Taupo, NZ). Proceedings of HydroEco 2009, 20-23 April 2009, Vienna, Austria. 171-174.

Stenger, R., Woodward, S.J.R., Clague, J., Wall, A., and Moorhead, B. (2010). How the spatial and temporal variation of reduced groundwater zones affects nitrate discharge into a wetland. In: The New Zealand Hydrological Society Conference, 7-10 December 2010, Dunedin, New Zealand.

Wang, F., Bright, J., and Hadfield, J. (2003). Simulating nitrate transport in an alluvial aquifer: A threedimensional N-dynamics model. Journal of Hydrology (New Zealand), 42, 145-162.

Wöhling, T., Vrugt, J.A., and Barkle, G.F. (2008). Comparison of three multiobjective optimization algorithms for inverse modeling of vadose zone hydraulic properties. Soil Science Society of America Journal, 72, 305-319.

Woodward, S.J.R., Bidwell, V.J., Burbery, L.F., Barkle, G.F., Hadfield, J., Park, J.W., and Close, M.E. (2010). How important is the spatial distribution of aquifer properties for nitrate discharge to surface waters? In: The New Zealand Hydrological Society Conference, 7-10 December 2010, Dunedin, New Zealand.

Woodward, S.J.R., Wöhling, T., Rajanayaka, C., and Wang, F. (2009). 3D modelling of nitrogen attenuation in coupled vadose zone-groundwater systems. In: The New Zealand Hydrological \& Freshwater Sciences Societies Joint Conference, 23-27 November 2009, Whangarei, New Zealand. 